(RESEARCH ARTICLE)

\title{
Duration of stay and outcome in different types of burn cases in paediatric age group
}

\author{
Satish Gadade ${ }^{1}$ and Monali Sonawane 2, * \\ ${ }^{1}$ Medical Superintendent, Sub district Hospital, Kavathe Mahankal, Sangli, Maharashtra. \\ ${ }^{2}$ Associate Professor, Department of Anatomy, Zydus Medical College and Hospital, Dahod, Gujarat.
}

Publication history: Received on 28 November 2020; revised on 07 December 2020; accepted on 10 December 2020

Article DOI: https://doi.org/10.30574/wjarr.2020.8.3.0467

\begin{abstract}
The incidence of burns, their treatment and rehabilitation have considerably marked effect on children both physically and psychologically. The hospital stay and the outcome also important in the cases of burns patients because the socio economic status and chances of life long disability. Aim of the study is to analyze the duration of stay and outcome in different types of burn cases in paediatric age group. The Data was collected from 83 paediatric patients less than 15 years admitted in GMC, Miraj, Maharashtra during the period from September 2014 to September 2016. The overall length of stay at hospital, factors influencing length of stay and outcome of patients were analyzed. Out of 83 patients 50 percent was cured over the period of time. The death rate was $10.8 \%$.Lower the percentage of burns had good outcome and higher percentage of burns had poor outcome $(66.7 \%$ had mortality when burns was $>60 \%)$. In the study $30 \%$ patients were cured with duration of stay 6 to 10 days. Out of subjects who died $44.4 \%$ stayed for less than 5 days in hospital, as they were having more \% of burn area. Also $72.7 \%$ patients who improved was stayed $<5$ days. Subjects cured in scald and flame burn were $60.66 \%$ and $59.1 \%$ respectively with no significant difference, while subjects died in scald and flame burn $6.56 \%$ and $22.72 \%$ respectively more in flame burn. In our study $8.4 \%$ of subjects underwent Escharotomy. It is concluded that surgical intervention increases the hospital stay and outcome of the mean duration of stay was high among subjects who deteriorated, followed by cured subjects. Lowest duration of hospital stay was observed among improved subjects, as they were having lower percent total body surface area (TBSA) burn. More hospital stay increase the chance of infections and vice versa.
\end{abstract}

Keywords: Burn injury; Pediatric Age; Total body surface area (TBSA)

\section{Introduction}

Burn injury is the frequent problem in clinical practice of general surgery. Burns are serious health problems and are frequent injury among paediatric patients. [1] The incidence of burns, their treatment and rehabilitation process have a considerably marked effect on children in both physical and psychological terms. Patients who suffer from burns often will have difficulties due to contractures, deformities and functional limitations caused by Scar tissue. Scar tissue treatment requires a prolonged period and also constitutes a heavy economic burden on families and the government. Burn injuries are a major problem in the low-income and middle-income countries. Paediatric burns may not only cause life-long disability, but also affect the mental health and quality of life of their families, imposing a socioeconomic burden. The hospital stay and the outcome are also important in the cases of burns patients because of the socio economic status and chances of life long disability.

\section{Aims and objectives}

Aim of the study was to analyze the duration of stay and outcome in different types of burn cases in paediatric age group.

\footnotetext{
${ }^{*}$ Corresponding author: Dr. Monali Sonawan

Associate Professor, Department of Anatomy, Zydus Medical College and Hospital,Dahod, Gujarat.

Copyright (C) 2020 Author(s) retain the copyright of this article. This article is published under the terms of the Creative Commons Attribution Liscense 4.0.
} 


\section{Material and Method}

The Data was collected from 83 paediatric patients less than 15 years getting admitted in our tertiary health care centre (GMC, Miraj, Maharashtra) during the period from September 2014 to September 2016. After obtaining ethical clearance from hospital and dully explained informed consent from parents or guardians of the burn patients from paediatric age group were enrolled for study. A detailed history of each patient was taken with history of present illness, past history personal history, family history and socio economic status was enquired. A special emphasis was given to mode of burn. A detailed general examination and systemic examination was done to know any associated disease to rule out any predisposing factor to aggravate complication in later stage. A local examination was done to calculate the percentage of total body surface area that is affected by burn injury. A detailed proforma was filled explaining the different affected body parts. The \% TBSA (total body surface area) was assessed by using a Lund Browder Chart. The burn depth was assessed clinically by observation of the burn wound. Burn injury management protocol was followed, surgical treatment like debridement (fasciotomy and escharotomy) are done as and if needed. Preventive measures like slab to prevent contracture were taken. The overall length of stay, factors influencing length of stay and the outcome of the patients were analyzed.

\section{Results}

Out of 83 patients 50 percent was cured over the period of time. The death rate was $10.8 \%$ during the period of time.

Table 1 Outcome among subjects with burns

\begin{tabular}{|l|l|l|l|}
\hline \multicolumn{2}{|l|}{} & Count (n) & Percentage (\%) \\
\hline \multirow{4}{*}{ Outcome } & Cured & 50 & $60.2 \%$ \\
\cline { 2 - 4 } & Improved & 22 & $26.5 \%$ \\
\cline { 2 - 4 } & Deteriorated (DAMA) & 1 & $1.2 \%$ \\
\cline { 2 - 4 } & Died & 9 & $10.8 \%$ \\
\cline { 2 - 4 } & Absconded & 1 & $1.2 \%$ \\
\cline { 2 - 4 } & Total & 83 & $100.0 \%$ \\
\hline
\end{tabular}

In the study significant association was observed between percentage of burns and outcome. Lower the percentage of burns had good outcome and higher percentage of burns had poorer outcome $(66.7 \%$ had mortality when burns was $>60 \%$ ).

Table 2 Association between percentage of burns and outcome

\begin{tabular}{|c|c|c|c|c|c|c|c|c|c|c|}
\hline \multirow{3}{*}{$\begin{array}{l}\text { TBSA } \\
\text { Percentag } \\
\text { e burns }\end{array}$} & \multicolumn{10}{|c|}{ Outcome } \\
\hline & \multicolumn{2}{|c|}{ Cured } & \multicolumn{2}{|c|}{ Improved } & \multicolumn{2}{|c|}{$\begin{array}{l}\text { Deteriorated } \\
\text { (DAMA) }\end{array}$} & \multicolumn{2}{|l|}{ Died } & \multicolumn{2}{|c|}{ Absconded } \\
\hline & $\begin{array}{l}\text { Coun } \\
t(n)\end{array}$ & $\begin{array}{l}\text { Percentag } \\
\text { e (\%) }\end{array}$ & $\begin{array}{l}\text { Coun } \\
t(n)\end{array}$ & $\begin{array}{l}\text { Percentag } \\
\text { e (\%) }\end{array}$ & $\begin{array}{l}\text { Coun } \\
t(n)\end{array}$ & $\begin{array}{l}\text { Percentag } \\
\text { e (\%) }\end{array}$ & $\begin{array}{l}\text { Coun } \\
t(n)\end{array}$ & $\begin{array}{l}\text { Percentag } \\
\text { e (\%) }\end{array}$ & $\begin{array}{l}\text { Coun } \\
t(n)\end{array}$ & $\begin{array}{l}\text { Percentag } \\
\text { e (\%) }\end{array}$ \\
\hline$<10 \%$ & 12 & $24.0 \%$ & 5 & $22.7 \%$ & 0 & $0.0 \%$ & 0 & $0.0 \%$ & 1 & $100.0 \%$ \\
\hline 11 to $20 \%$ & 16 & $32.0 \%$ & 8 & $36.4 \%$ & 0 & $0.0 \%$ & 0 & $0.0 \%$ & 0 & $0.0 \%$ \\
\hline 21 to $30 \%$ & 10 & $20.0 \%$ & 6 & $27.3 \%$ & 0 & $0.0 \%$ & 0 & $0.0 \%$ & 0 & $0.0 \%$ \\
\hline 31 to $40 \%$ & 6 & $12.0 \%$ & 1 & $4.5 \%$ & 0 & $0.0 \%$ & 1 & $11.1 \%$ & 0 & $0.0 \%$ \\
\hline 41 to $60 \%$ & 5 & $10.0 \%$ & 2 & $9.1 \%$ & 0 & $0.0 \%$ & 2 & $22.2 \%$ & 0 & $0.0 \%$ \\
\hline$>60 \%$ & 1 & $2.0 \%$ & 0 & $0.0 \%$ & 1 & $100.0 \%$ & 6 & $66.7 \%$ & 0 & $0.0 \%$ \\
\hline
\end{tabular}

In the study $30 \%$ patients was cured with duration of stay 6 to 10 days. Out of 9 subjects who died $44.4 \%$ stayed for less than 5 days in hospital, as they were having more \% of burn area. Also 16 (72.7\%) patients out of 22 who improved was stayed $<5$ days. 
Table 3 Association between duration of stay and outcome

\begin{tabular}{|c|c|c|c|c|c|c|c|c|c|c|}
\hline \multirow{3}{*}{$\begin{array}{c}\text { Duration } \\
\text { of stay }\end{array}$} & \multicolumn{10}{|c|}{ Outcome } \\
\hline & \multicolumn{2}{|c|}{ Cured } & \multicolumn{2}{|c|}{ Improved } & \multicolumn{2}{|c|}{$\begin{array}{l}\text { Deteriorated(D } \\
\text { AMA) }\end{array}$} & \multicolumn{2}{|c|}{ Died } & \multicolumn{2}{|c|}{ Absconded } \\
\hline & $\begin{array}{l}\text { Cou } \\
\text { nt } \\
\text { (n) }\end{array}$ & $\begin{array}{l}\text { Percent } \\
\text { age (\%) }\end{array}$ & $\begin{array}{l}\text { Cou } \\
\text { nt } \\
\text { (n) }\end{array}$ & $\begin{array}{l}\text { Percent } \\
\text { age (\%) }\end{array}$ & $\begin{array}{l}\text { Count } \\
\text { (n) }\end{array}$ & $\begin{array}{l}\text { Percent } \\
\text { age (\%) }\end{array}$ & $\begin{array}{l}\text { Cou } \\
\text { nt } \\
\text { (n) }\end{array}$ & $\begin{array}{l}\text { Percent } \\
\text { age (\%) }\end{array}$ & $\begin{array}{l}\text { Cou } \\
\text { nt } \\
\text { (n) }\end{array}$ & $\begin{array}{l}\text { Percent } \\
\text { age (\%) }\end{array}$ \\
\hline$<5$ days & 11 & $22.0 \%$ & 16 & $72.7 \%$ & 0 & $0.0 \%$ & 4 & $44.4 \%$ & 1 & $100.0 \%$ \\
\hline 6 to 10 days & 15 & $30.0 \%$ & 3 & $13.6 \%$ & 0 & $0.0 \%$ & 2 & $22.2 \%$ & 0 & $0.0 \%$ \\
\hline $\begin{array}{l}11 \text { to } 15 \\
\text { days }\end{array}$ & 13 & $26.0 \%$ & 3 & $13.6 \%$ & 0 & $0.0 \%$ & 1 & $11.1 \%$ & 0 & $0.0 \%$ \\
\hline $\begin{array}{l}15 \text { to } 20 \\
\text { days }\end{array}$ & 4 & $8.0 \%$ & 0 & $0.0 \%$ & 0 & $0.0 \%$ & 2 & $22.2 \%$ & 0 & $0.0 \%$ \\
\hline$>20$ days & 7 & $14.0 \%$ & 0 & $0.0 \%$ & 1 & $100.0 \%$ & 0 & $0.0 \%$ & 0 & $0.0 \%$ \\
\hline
\end{tabular}

In the study Mean duration of stay was high among one subject who deteriorated, followed by cured subjects. Lowest duration of hospital stay was observed among improved subjects, as they were having lower \%TBSA burn. This difference in duration of stay with respect to outcome was statistically significant.

Table 4 Association between type of burn and outcome

\begin{tabular}{|c|c|c|}
\hline Outcome & Scaled & Flame \\
\hline Cured & $37(60.66 \%)$ & $13(59.1 \%)$ \\
\hline Improved & $19(31.14 \%)$ & $3(13.64 \%)$ \\
\hline Deteriorated (DAMA) & 0 & $1(4.54 \%)$ \\
\hline Died & $4(6.56 \%)$ & $5(22.72 \%)$ \\
\hline Absconded & $1(1.64 \%)$ & 0 \\
\hline
\end{tabular}

Subjects cured in scald and flame burn are $60.66 \%$ and $59.1 \%$ respectively with no significant difference, while subjects died in scald and flame burn $6.56 \%$ and $22.72 \%$ respectively more in flame burn.

\section{Discussion}

In the current study $60.24 \%$ subjects were cured, $26.5 \%$ improved with overall mortality rate of $10.84 \%$ which is comparable to Chalya PL et al. 2011 study with overall mortality rate was $11.7 \%$.[2]

In the study mean duration of stay was high among one subject who deteriorated (\& went DAMA), followed by cured subjects. Lowest duration of hospital stay was observed among improved subjects. , as they were having lower \%TBSA burn. This difference in duration of stay with respect to outcome was statistically significant. The results corresponds to study done by Milenkovic M et al.2004. [3]

The overall duration of stay in current study ranges from 1 to 35 days with mean $9.5 \pm 7.8$ days which is comparable to PJR et al study with overall duration of stay ranging from 1 to 86 days with mean $27.12 \pm 16.62$ days. This result nearly in accordance to the previous studies were done in pediatric burn wards. [4-8]

In Yavuz et al. 2011 study the average duration of stay was $17.67 \pm 13.64$ days, longest stay in Tandir burn. [9]

In current study 7 (8.4\%) subjects were given surgical treatment by eschorotomy and debridement. 
These findings are comparable to to Chalya PL et al .2011 study with 44 (12.9\%) subjects given surgical treatment. Out of 44 subjects, 29 (45.9\%) patients underwent skin grafting, 5(11.4\%) patients underwent fasciotomy and escharotomy, and $4(9.1 \%)$ patients underwent wound debridement.

\section{Conclusion}

Burns are serious health problems and are most frequent injury among pediatric patients. The surgical intervention increases the hospital stay. The idea of the study to show outcome of the mean duration of stay was high among subjects who deteriorated, followed by cured subjects. Lowest duration of hospital stay was observed among improved subjects, as they were having lower \%TBSA burn. More hospital stay increase the chance of infections and vice versa.

\section{Compliance with ethical standards}

\section{Acknowledgments}

We sincerely thank the institution to allow us the permission for this work. We also thank Dr. Nitin Hombalkar, Associate professor Surgery, GMC Miraj, Maharashtra, for his valuable guidance and suggestions while carrying out this project.

\section{Disclosure of conflict of interest}

None.

\section{Statement of informed consent}

Informed consent was obtained from parents of all the participants included in the study.

\section{References}

[1] Posner JC, Hawkins LA, Garcia - Espana F, Durbin DR: A randomized clinical trial of a home safety intervention based in an emergency department setting. Pediatrics. 2004; 113(6): 1603-1608.

[2] Chalya PL, Mabula JB, Dass RM, Giiti G, Chandika AB, Kanumba ES, Gilyoma JM. Pattern of childhood burn injuries and their management outcome at Bugando Medical Centre in Northwestern Tanzania. BMC research notes. 2011 Nov 9; 4(1): 1 .

[3] Milenkovic M, Russo A, AnneElixhauser. Hospital Stays for Burns, Statistical Brief \#25. Agency for Healthcare Research and Quality. USA. 2007. Available from: https://www.ncbi.nlm.nih.gov/books/NBK63486/

[4] Al-Zacko SM, Zubeer HG, Mohammad AS. Pediatric burns in Mosul: an epidemiological study. Ann Burns Fire Disasters. 2014; 27(2): 70-75.

[5] Rafii MH, Saberi HR, Hosseinpour M, et al. Epidemiology of pediatric burn injuries in isfahan, iran. Arch Trauma Res. 2012; 1(1): 27-30.

[6] Behzadnia S, Davoudi A, Rezai MS, et al. Nosocomial infections in pediatric population and antibiotic resistance of the causative organisms in north of iran. Iran Red Crescent Med J. 2014; 16(2): e14562.

[7] Duke J, Wood F, Semmens J, et al. A study of burn hospitalizations for children younger than 5 years of age: 19832008. Pediatrics. 2011; 127(4): e971-977.

[8] Karimi H, Montevalian A, Motabar AR, et al. Epidemiology of paediatric burns in Iran. Ann Burns Fire Disasters. 2012; 25(3): 115-120.

[9] Yavuz A, Ayse A, Abdullah Y, Belkiz A. Clinical and demographic features of paediatric burns in the eastern provinces of Turkey. Scandinavian journal of trauma, resuscitation and emergency medicine. 2011 Jan 18; 19(1): 1. 